\title{
(Inter)nationalistisk folkbildning: Säkerhetspolitik, nationalism och opinionsbildning i den svenska folkhögskolans mobilisering för utvecklingsfrågor 1950-1969
}

\author{
Sofia Österborg Wiklund
}

\begin{abstract}
Inter)nationalist Popular Education: Security Policy, Nationalism and Advocacy in the Swedish Folk High Schools' Action on Development Issues 1950-1969 • Folk High Schools in Sweden have a long history of engaging internationally, especially as regards courses on development studies (u-landslinjer) that emerged in the late sixties. The purpose of this article is to track some of the discourses about internationalisation, development and aid that preceded those courses, as well as to scrutinise ideas of the role of the Folk High School (folkhögskola) in the emerging field of development aid. Analysing material from Tidskrift för svenska folkhögskolan (Journal of the Swedish Folk High School) between 1950 and 1969, the study shows that the discourse on internationalism takes its starting point from an already established nationalism and nordism. National security also arises as an argument for engaging in development issues. The analysis also shows that there is a shift in the role of the Folk High School in the evolving development work; from "helping" to "advocating." The results raise questions about how we can understand today's Folk High School courses on global development against the background of the debates of the fifties and sixties.
\end{abstract}

Keywords • Folk High Schools [folkhögskolor], development aid [u-landslinjer], nationalism, Sweden [Sverige]

\section{Om folkhögskolans internationella engagemang}

\begin{abstract}
Har det en gång kunnat sägas, att vår stuga är för trång (med trängsel bl.a. av traditioner) och utan utblick, så gäller det i varje fall inte nu. Istället finns i alla länders folkhögskolor en strävan efter kontakter - inte minst över gränserna - så stark att den kan sägas känneteckna vår skolform idag. ${ }^{1}$
\end{abstract}

Citatet är hämtat från en artikel i den fackliga Tidskrift för svenska folkhögskolan (hädanefter kallad TSF) under efterkrigstidens 50-tal. Det speglar en omvälvande period, såväl inom folkhögskolevärlden som världspolitiskt. I folkhögskollärarnas fackliga och tämligen inflytelserika tidskrift, liksom i andra forum, diskuteras folkhögskolans roll i en, på samma gång, allt mer sammankrympande och utvidgande värld. Inom loppet av femton år utökar folkhögskolan kraftigt sin internationella verksamhet jämfört med skolformens första århundrade. ${ }^{2}$ I samband med 60- och

1 Tidskrift för svenska folkhögskolan (TSF) 1954:2, 82.

2 Tomasz Maliszewski, Den svenska folkhögskolan: En betraktelse från andra sidan Östersjön (Linköping: Vuxenutbildarcentrum, 2008).

Sofia Österborg Wiklund is a Doctoral Student in Education and Adult Learning at the Department of Behavioural Sciences and Learning, Linköping University, Sweden.

Email: sofia.osterborg.wiklund@liu.se 
70-talens politiska radikalisering, och i kölvattnet av en allmän redan väl etablerad missionstradition ${ }^{3}$ börjar folkhögskolorna organisera särskilda "u-landslinjer"; kurser med fokus på biståndspolitik, så kallade "u-landsfrågor", ofta med en studieresa till ett "u-land".

Folkhögskolan träder här, organisatoriskt och diskursivt, in på ett större fält för svenskt internationellt hjälp-, solidaritets- och biståndsarbete som höll på att växa fram både i Sverige och internationellt under samma tidsepok. ${ }^{4}$ Det som då kallades u-landslinjer, rubriceras med folkhögskoletermer idag mer ofta som kurser i global utveckling. ${ }^{5}$ De utgör fortfarande en beaktansvärd del av utbudet på de 154 folkhögskolorna i Sverige, och flera kurser har genom åren bedrivits med anknytning till biståndsmyndigheten Sida, parallellt med förankring i olika folkrörelser. ${ }^{6}$ I efterhand har den internationella verksamheten beskrivits som att ha blivit en av de viktigaste inriktningarna för folkhögskolan efter $1968 .^{7}$

Med kopplingen till både folkbildningen och biståndet som samhälleliga institutioner, och dess respektive betydelse för svensk nationell självbild, kan u-landslinjerna ses som unika i sitt slag och som skiljer sig från andra typer av internationellt volontärarbete. Trots den långa historien av internationellt arbete inom folkhögskolan finns det dock fortfarande förhållandevis lite forskning på hur uppkomsten av särskilda u-landslinjer kan förstås historiskt och ur ett samhälleligt perspektiv. Tidigare folkbildningsforskning har problematiserat hur makt, koloniala och nationella föreställningar har reproducerats i transnationella folkbildande praktiker, trots att de har haft till syfte att motverka detsamma. Detta är en kritisk genre inom folkbildningsforskningen som den här studien ansluter sig till, med fokus på hur ideologi, som exempelvis föreställningar av nation, tar sig uttryck i folkbildande praktiker.

Den här artikeln syftar således till att spåra några av de diskurser om internationalisering, utveckling och bistånd, som under sent 60-tal kom att materialiseras i särskilda u-landslinjer på folkhögskolan. Syftet är också att undersöka förändringar över tid samt att relatera dessa till omgivande, historiska kontexter. För detta syfte är jag inspirerad av den kritiska diskursanalysen (CDA) och ideologi som "betydelser i maktens tjänst", främst med fokus på hur nation skapas. Varför skulle folkhögskolan "internationaliseras" och vilken innebörd ges internationalisering över tid? Hur skulle detta ske, och vilka skulle det beröra? Vilken roll och betydelse ges åt folkhögskolan som aktör inom de framväxande arenorna för bistånd i Sverige och internationellt? Hur kan detta förstås ideologiskt och i förhållande till Sverige som nation? Fokus ligger på texter som har publicerats i Svenska Folkhögskolans Lärarförbunds (SFHL) publikation Tidskrift för svenska folkhögskolan mellan 1950 och 1969, detta för att få tillgång till en intern, men ändå relativt offentlig, debatt från en inflytelserik

3 Jmf t.ex. Cecilia Jonsson, Volontärerna: Internationellt hjälparbete från missionsorganisationer till volontärresebyråer (Växjö: Linnéuniversitetet, 2012); Sunniva Engh, "The Conscience of the World? Swedish and Norwegian Provision of Development Aid," Itinerario 33, nr 2 (2009).

4 Jmf Jonsson (2012); Björn Hettne, Vad är utveckling? (Stockholm: SNS förlag, 2008); Bertil Odén, Biståndets idéhistoria: Från Marshallhjälp till millenniemål (Lund: Studentlitteratur, 2006).

5 Sofia Österborg Wiklund, "Från u-landslinje till global rättvisekurs: Om resande kurser i folkhögskolans kurskataloger 1983-2014," i Folkbildning \& forskning: årsbok 2014/15 (Stockholm: Föreningen för Folkbildningsforskning, 2015).

6 Erik Nylander, Kerstin Mustel och Therése Jansson, Gränsöverskridande folkbildning: Om resurser, nätverk och transnationellt engagemang (Stockholm: Folkbildningsrådet, 2011).

7 Maliszewski (2008). 
arena. Tidskriften utgörs dessutom av ett detaljrikt material som ger betydelsefulla inblickar i hur u-lands- och globala utvecklingskurser har fått sin plats inom folkhögskolan.

\section{Forskning om folkhögskolans transnationella arbete}

Den tidigare forskningen om den svenska folkhögskolans u-landslinjer är som nämnts inte särskilt omfattande. Det finns några få studier som berör u-landslinjer specifikt, och fler som rör internationella aspekter av folkbildning generellt.

År 2011 utkom Mimer med en rapport i samarbete med folkbildningsrådet, som via en enkätundersökning kartlägger folkbildningens transnationella aktiviteter under 2009. Resultatet visar på att verksamheten i första hand bedrevs i enlighet med folkbildningspropositionens sjunde område som rörde folkhälsa, hållbar utveckling och global rättvisa. Resemönstren var koncentrerade till södra halvklotet och en stor del av verksamheten drevs med medel från Sida eller någon biståndsorganisation. ${ }^{8}$ Erik Nylander och Song-Eeh Ahn jämför vidare folkhögskolans internationella mobilitet med högskolans, och kartlägger det geografiska mönster som präglar folkhögskolans resandekurser, samt knyter an till symboliska värden som tillerkänns i internationella studeranderesor. De menar att det går att skönja en skillnad mellan folkhögskolans och högskolans mobilitet, då högskolan präglas av mer arbetsmarknadsstrategiska, och folkhögskolan mer sociala värden. ${ }^{9}$

Tomasz Maliszewski nämner u-landslinjerna och folkhögskolans internationalisering i ett arbete rörande den svenska folkhögskolan generellt. Författaren tar upp kursernas tillkomst och framväxt, och nämner Olof Palme som en viktig politisk aktör. ${ }^{10}$ Katarina Leppänen har studerat internationalism i den nordiska folkhögskolan i Geneve, som syftade till att öka "international citizenship proficiency" under mellankrigstiden. Leppänen studerar de ideologiska spänningar som omgärdade de olika uppfattningarna om internationalism som företräddes av dels representanter för internationella organisationer, dels vuxenutbildare. ${ }^{11}$ Kerstin Wallin har studerat svenskt fackligt bistånd från Sverige till Chile, och belyser förutsättningar och den pedagogiska miljön för att "exportera" studiecirkelformen till de fackliga aktörerna i Chile. ${ }^{12}$

Magnus Dahlstedt och Henrik Nordvall, samt Linda Berg analyserar folkbildnings(sam)arbete mellan Sverige och Tanzania respektive Nicaragua ur postkoloniala perspektiv. ${ }^{13}$ Nordvall och Dahlstedt undersöker relationen mellan svensk folkbildning och etableringen av Folk Development Colleges, FDC, i Tanzania, formandet av nationella självbilder och andrafiering av samarbetspartners när svenska

8 Nylander et al. (2011)

9 Erik Nylander och Song-Eeh Ahn, "Vart leder internationaliseringen?" i Lärandets mångfald: Om vuxenpedagogik och folkbildning, red. Andreas Fejes (Lund: Studentlitteratur, 2013), 209-29.

10 Maliszewski (2008).

11 Katarina Leppänen, "Education for Internationalism at the Nordic School for Adult Education in Geneva 1931-1939," History of Education 40, nr 5 (2011), 635-49.

12 Kerstin E. Wallin, Folkbildning på export? Sammanhang, förutsättningar, möjligheter (Stockholm: Stockholms universitet, 2000).

13 Magnus Dahlstedt och Henrik Nordvall, "Paradoxes of Solidarity: Democracy and Colonial Legacies in Swedish Popular Education," Adult Education Quarterly $61 \mathrm{nr} 244$ (2011); Linda Berg, InterNacionalistas: Identifikation och främlingskap i svenska solidaritetsarbetares berättelser från Nicaragua (Umeå: h:ström, 2007). 
folkbildningsidéer exporteras till andra delar av världen. Här blir en solidaritetens paradox central för att belysa hur strävan efter att bryta med ett kolonialt arv blandas med koloniala diskurser om identitet och tillhörighet, demokrati och modernitet. ${ }^{14}$ Detta berör även Berg, som analyserar skildringar från svenska solidaritetsarbetare i Nicaragua och belyser identitet och svårigheterna att åstadkomma gemenskaper i en postkolonial samtid. ${ }^{15}$

Det finns också studier och litteratur i gränslandet för den akademiska genren som behandlar u-landslinjerna mer specifikt. Clara Hyldegaard Nankler gör en historisk genomgång av folkhögskolans globala arbete, och pekar bland annat på de samarbeten som skedde mellan folkhögkolorna och Sida. ${ }^{16}$ Rolf Berndtsson beskriver framväxten av Den Rejsende Höjskolen i Danmark, och dess betydelse för folkhögskolornas resandekurser i Sverige. ${ }^{17}$ Inger Landström jämför internationella kurser och folkbildningspedagogik i de olika nordiska länderna. ${ }^{18}$

Ingen av ovanstående studier gör dock ett historiskt nedslag utifrån kritisk teoribildning angående uppkomsten av kurserna, med vilket den här studien bidrar.

\section{Kritiskt diskurshistoriska ansatser}

För att fånga ideologiska verkningar, maktrelationer och förändring över tid, har jag i denna artikel inspirerats av teori och metod från den kritiska diskursanalysen (CDA) och dess diskurshistoriska förgrening (DHA), såsom de företräds av bland andra Ruth Wodak och Norman Fairclough. ${ }^{19}$ CDA och DHA har i stor utsträckning använts för att avtäcka ideologi kopplat till rasism, nationalism och nationell identitet i Europa i både nutida och historiska perspektiv. Ideologi förstås här som "betydelser i maktens tjänst". ${ }^{20}$ Syftet med CDA är "[...] to investigate critically social inequality as it is expressed, signalled, constituted, legitimized and so on by language use (or in discourse)." ${ }^{21}$ Teori och metod är tätt sammankopplade, samtidigt som jag via det kritiska i diskursanalysen ansluter mig till ett empiriskt icke-neutralt förhållande till maktrelationer och social förändring. ${ }^{22}$ Metodmässigt har jag valt att ta fasta på några analytiska begreppsverktyg, snarare än att följa ett helt koncept.

14 Henrik Nordvall och Magnus Dahlstedt, "Folkbildning i (av)koloniseringens skugga," Utbildning \& Demokrati 18, nr 3 (2009), 29-47.

15 Berg (2007).

16 Clara Hyldgaar Nankler, "Folkhögskolans globala engagemang," Årsbok om folkbildning (Stockholm: Föreningen för folkbildningsforskning, 2014).

17 Rolf Berndtsson, Nya folkhögskolor: En uppföljningsstudie av de folkhögskolor som blivit självständiga mellan åren 1991 och 2000 (Stockholm: Folkbildningsrådet, 2003).

18 Inger Landström, ”Den nordiska folkhögskolans globala medborgare: Folkbildningspedagogik med internationella förtecken," i Två sidor av samma mynt?: Folkbildning och yrkesutbildning vid de nordiska folkhögskolorna, red. Fay Lundh Nilsson och Anders Nilsson (Lund: Nordic Academic Press, 2010).

19 Se t.ex. Norman Fairclough, Discourse and Social Change (Cambridge: Polity, 1992); Ruth Wodak "The Discourse Historical Approach," i Methods of Critical Discourse Analysis, red. Ruth Wodak och Michael Meyer (London: SAGE, 2001), 63-94.

20 Norman Fairclough, Critical Discourse Analysis: The Critical Study of Language (Harlow: Longman, 2010).

21 Ruth Wodak och Michael Meyer, red., Methods of Critical Discourse Analysis (London: SAGE, 2001), 2.

22 Fairclough (1992); Wodak och Meyer, red. (2001). 
Relationen mellan diskurs och det sociala är i den kritiska diskursanalysen dialektiskt, och diskurser formar och är formade av institutioner, situationer och strukturer. ${ }^{23}$ Det betyder här att det tal som kommer till uttryck i TSF är format av, och medskapare till, de materiella och strukturella villkor som det diskursiva eventet är inbäddat i. I den historiska diskursanalysen utgör just kontexten en viktig dimension i analysen. Jag har här tagit fasta på de så kallade "middle range theories", det vill säga forskning om folkbildning och bistånd, samt "grand theories" och tillämpningar av dessa i en svensk kontext.

Liksom Wodak med flera ${ }^{24}$ relaterar jag till Benedict Andersons klassiska definition av nation, som "imagined communities" - föreställda gemenskaper, som inte går att skilja från varandra genom autenticitet, utan "by the way in which they are imagined", 25 liksom Stuart Halls beskrivning av nationell kultur som en diskurs och:

a way of constructing meanings which influences and organises both our actions and our conception of ourselves [...] National cultures construct identities by producing meanings about 'the nation' with which we can identify; these are contained in the stories which are told about it, memories which connect its present with its past, and imagines which are constructed of it. ${ }^{26}$

Vidare utgår jag från en förståelse av att Sverige, tillsammans med de andra nordiska länderna, är formad av en kolonial världshistoria som fortsätter skapa rasifierade maktrelationer. ${ }^{27}$ Detta sker samtidigt som Sveriges internationella relationer ses som präglade av bistånd och fredsbyggande snarare än kolonialism och imperialism. ${ }^{28}$ En "nordisk exceptionalism" är central för svensk nationell självbild. ${ }^{29}$ Bilden av svenskhet går här hand i hand med en föreställning av svenskhet som vithet, och som tar sig uttryck på olika sätt. ${ }^{30}$

Begreppet internationalisering kommer både från empiri och teori. Som del i en större "grand theory" klassas Globalisering i det här utbildningsvetenskapliga sammanhanget som "the economic, political, and societal forces pushing 21 st century higher education toward greater international involvement" och internationalisering som ett resultat av detta; "the policies and practices undertaken by academic systems

23 Michelle Lazar, Feminist Critical Discourse Analysis: Gender, Power, and Ideology in Discourse, (New York: Palgrave Macmillan, 2005); Fairclough (1992).

24 Ruth Wodak, red., The Discursive Construction of National Identity (Edinburgh: Edinburgh University Press, 2009).

25 Benedict Anderson, Imagined Communities: Reflections on the Origin and Spread of Nationalism (London: Verso, 1983), 15.

26 Stuart Hall, "The Question of Cultural Identity," i Modernity: An Introduction to Modern Societies, red. Stuart Hall, David Held, Don Hubert and Kenneth Thompson (Malden: Blackwell, 1996), 613.

27 Se t.ex. Kristín Loftsdóttir och Lars Jensen, red., Whiteness and Postcolonialism in the Nordic Region: Exceptionalism, Migrant Others and National Identities (Farnham: Ashgate, 2012); Suvi Keskinen, Salla Touri, Sara Irni och Diana Mulinari, Complying with Colonialism: Gender, Race and Ethnicity in the Nordic Region (New York: Routledge, 2009).

28 Keskinen, et al., (2009).

29 Loftsdóttir och Jensen, red. (2012).

30 Se Keskinen et al. (2009); Loftsdóttir och Jensen, red. (2012), Tobias Hübinette och Catrine Lundström "Three Phases of Hegemonic Whiteness: Understanding Racial Temporalities in Sweden," Social Identities: Journal for the Study of Race, Nation and Culture 20, nr 6 (2014), 423-37. 
and institutions - and even individuals - to cope with the global academic environment." 31

För att studera hur olika diskurser rör sig mellan olika institutioners diskursordningar, det vill säga "the totality of its discursive practices, and the relationships (of complementarity, inclusion/exclusion, opposition) between them [... "32, använder jag mig av begreppsverktyget interdiskursivitet; ${ }^{33}$ exempelvis kan biståndsdiskurser användas inom folkhögskolans diskursordning och vice versa. För att analysera tidsspannet 1950-1969 har jag fokuserat på förändring som pågår i materialet. Utifrån detta har jag läst materialet med fokus på talet om u-land, global utveckling och internationalisering. Här har jag framför allt fokuserat på vad som sägs, hur det sägs, varför frågorna är viktiga och hur budskapen legitimeras. ${ }^{34}$ Här är samspelet mellan att skapa sameness och difference, ett identitetsmässigt skillnads- och likhetskapande, ett användbart verktyg för att förstå hur nation görs i texten. ${ }^{35}$

För att markera att det rör sig om tids- och platsspecifika ideologiskt impregnerade diskurser har jag ibland valt att i beskrivande och analyserande text återge begrepp såsom "u-land" eller "u-landsfrågor", istället för att byta ut det mot mer adekvata begrepp.

\section{Tidskrift för svenska folkhögskolan: En central arena för folkhögskoledebatt} För att få tillgång till en offentlig men ändå relativt intern folkhögskoledebatt har jag använt mig av texter såsom artiklar, notiser och ledare från Tidskrift för svenska folkhögskolan (TSF) 1950 till och med 1969. Tidskriften är facklig och har sedan starten utgjort en viktig arena för debatten rörande folkhögskolans roll i samhället. ${ }^{36}$ Tidskriften har även utgjort referens för ytterligare folkbildningsforskning i egenskap av viktigt organ för åsiktsutbyte och representation ${ }^{37}$. Skribenterna i tidskriften är företrädesvis lärare och rektorer. Tidskriften tillhandahåller exempel på hur folkhögskollärare bör förhålla sig i olika frågor. ${ }^{38}$

Den analyserade tidsperioden är avgränsad till 1950-1969, detta för att kunna fixera de diskussioner som föregick och ledde fram till de u-landslinjerna som uppkom i slutet av 60-talet. Den avgränsade periodens utgångspunkt är 1950 på grund av att det var under efterkrigstiden som talet om internationalisering av folkhögskolan intensifierades och u-landsbegreppet började användas i TSF.

Som med alla avgränsningar innebär ett urval ett uteslutande av möjliga andra berättelser. I det här fallet innebär det empiriska valet av TSF under 50- och 60-ta-

31 Philip G. Altbach och Jane Knight, "The Internationalization of Higher Education: Motivations and Realities," Journal of Studies in International Education 11, nr 3-4 (2007), 290.

32 Fairclough (2010), 93.

33 Wodak (2001); Fairclough (1992).

34 Jmf Wodak och Meyer, red. (2001).

35 Ruth Wodak och Salomi Boukala "European identities and the revival of nationalism in the European Union: a discourse-historical approach," Journal of Language \& Politics 14, $\mathrm{nr} 1$ (2015), 87-109; Anna Triandafyllidou och Ruth Wodak, "Conceptual and Methodological Questions in the Study of Collective Identities," Journal of Language \& Politics 2, nr 2 (2003), 205-23; Wodak och Meyer, red. (2001).

36 Maliszewski (2008).

37 Caroline Runesdotter, I otakt med tiden? Folkhögskolorna i ett föränderligt fält (Göteborg: Göteborgs universitet, 2010); Annelie Andersén, Ett särskilt perspektiv på högre studier? Folkhögskoledeltagares sociala representationer om högskola och universitet (Jönköping : Högskolan i Jönköping, 2011).

38 Andersén (2011). 
len en koncentrering till nästan uteslutande (manliga) lärare, rektorer och andra företrädare på de svenska folkhögskolorna. Motparterna i samarbetsorganisationer framträder inte alls i materialet och rapporteringar från deras debatter började förekomma, om än i relativt liten utsträckning, först på 70-talet. Inte heller går det att via materialet fånga diskussioner som förs utanför tidskriftssammanhanget, såsom policydokument eller andra officiella skrivelser. Mitt syfte är dock inte att kartlägga alla aspekter av tidsperioden, utan syftet är att spåra några inflytelserika diskurser i den mening att de upptagit utrymme i folkhögskollärarnas fackförbunds tidskrift. Det resultat som här presenteras ska inte heller läsas som en redogörelse för de mest dominerande diskurserna, någon sådan rangordning har analytiskt inte gjorts i läsningen av materialet, utan resultatet ska främst ses som olika förekommande ideologiska uttryck med relevans för det teoretiska ramverket. Vidare vill jag också understryka att, trots att jag anser representation viktig och att vem som säger vad och när spelar roll, så har det inte funnits utrymme för att inkludera de olika skribenternas enskilda positioner $i$ analysen. Jag har istället fokuserat på vad som uttrycks i materialet, snarare än på personerna bakom.

Urvalet av texter bygger på en tidigare förstudie om vilka begrepp som använts $\mathrm{i}$ folkhögskolekurskataloger mellan 1983 och $2014 .{ }^{39}$ Detta för att få en tydlig koppling till u-landslinjerna och de globala rättvisekurserna. "Internationell", "u-land", "utveckling", "global", "hållbar", "bistånd" är därför begrepp som jag har utgått från i urvalet, även om jag haft en öppen blick för även andra texter som mer implicit kan ha behandlat ovanstående frågor. Texter som inte har haft ett tydligt fokus på utvecklingsfrågor har legat utanför studiens område och därmed uteslutits.

Materialet, som består av elva artiklar från 50-talet och 56 artiklar från 60-talet, har katalogiserats med titel, skribentens namn, sidnummer och årgång. Jag har även katalogiserat texter från 1920 till 2010, och som inte berörs i denna artikel. Dessa fyller en viss funktion som referensram i tolkningarna av den valda tidsperioden.

\section{Nationalism, säkerhetspolitik och opinionsbildning för internationalisering} I talet i TSF om folkhögskolans behov av en utomnordisk och utomeuropeisk internationalisering, går debatterna från att knappt existera till att under 50-talet intensifieras och senare, under 60-talets slut, bland annat materialiseras i de särskilda u-landslinjerna. U-landslinjerna kom senare att under 70- och 80-talet blir etablerade institutioner och koncept för folkhögskolans engagemang i svenskt internationellt bistånds-, missions- och solidaritetsarbete.

Även om de internationella frågorna hade varit på tapeten en längre tid är det först under 60-talet som skribenterna på allvar börjar sia om u-landshjälpens intåg på folkhögskolan, inte minst i samband med ombildandet av Centralkommittén till Nämnden för internationellt bistånd, NIB (1962), sedermera Sida (1965), samt det ökande intresset för internationella frågor i samhällsdebatten generellt. Hela 60-talet brukar beskrivas som präglad av utvecklingsoptimism, och utropades av FN till "utvecklingsårtiondet". ${ }^{40}$ Det är i och med 60-talet som särskilda kurser om "u-land" förutspås bli nödvändiga på folkhögskolorna i TSF, gärna i samarbete med Sida. ${ }^{41}$

39 Österborg Wiklund (2015).

40 Odén (2006).

41 TSF 1966:9, $181 f$. 
Samma år har även tidskriften sitt första av flertalet följande temanummer med internationell inriktning. ${ }^{42}$ Skribenter går här från att under 50- och 60-talen betona behovet att vara med och skapa allmän opinion för u-landsfrågorna, till att i samband med 68-rörelsen betona folkhögskolans behov av att möta "allt starkare krav på internationellt engagemang" utifrån. ${ }^{43}$ Sida och folkhögskolan blir också interpersonellt sammanflätade bland annat i bemärkelsen att personer på viktiga positioner var aktiva inom båda sfärer. Exempelvis var den i TSF ofta medverkande Torgil Ringmar både rektor på Åsa folkhögskola och arbetade som chef på Sida under 60- och 70-talet. ${ }^{44}$ TSF kom att ha flera samarbeten med Sida, inte minst i samband med de temanummer med internationellt fokus som publicerades under tidsperioden och framåt.

Jag kommer här lyfta fram några diskurser och skiften som är tongivande i materialet, och som ger ledtrådar till hur det internationella på folkhögskolans kan förstås historiskt och i sin samtid. Den första diskussion jag vill belysa är hur internationaliseringen av folkhögskolan blir föremål för stridigheter gällande den i folkbildningen rotade nationalismen och nordismen som artikuleras i materialet. Den andra diskussion som berörs är hur säkerhetspolitiska argument används för att mobilisera engagemang för u-landshjälp. Den tredje diskussionen rör vilken roll folkbildningen får spela i uppslutningen kring utvecklingsfrågorna.

\title{
Internationalisering via nationalism, nordism och nationalromantik
}

\begin{abstract}
Den svenska folkhögskolestadgans målsättning är enligt min uppfattning för trång. [...] Det räcker inte med fostran till nationell samhörighet, ehuru den uppgiften alltjämt kvarstår. Vi måste alla fostras till européer och till världsmedborgare. Av alla skolformer är folkhögskolan den som lagt störst vikt vid medborgarfostran. Just därför borde folkhögskolan mer än andra skolor ta som sin uppgift att vidga och fördjupa medborgarskapet i vår ständigt sammankrympande värld. ${ }^{45}$
\end{abstract}

Citatet ovan kommer från en inledning till ett tidskriftsnummer 1954 och tar avstamp i en debatt om nationell samhörighet och medborgarfostran som nyligen (om)aktualiserats inom folkhögskolan. När de internationella frågorna börjar ta plats i TSF under 50-talet blir de genast föremål för debatt utifrån de redan etablerade nationalistiska och nordistiska ambitionerna med folkhögskolans varande och uppdrag. Ett viktigt debattämne under 50-talet är ändringen av folkhögskolestadgan. Debatten rörde omskrivelsen att folkhögskolan bland annat skulle syfta till att öka deltagarnas förståelse för samhörigheten med olika folk och därför orientera dem i förhållandena i andra länder och mellanfolkligt samarbete, i kontrast till den tidigare skrivelsen som betonade den nationella samhörigheten. ${ }^{46}$

Nationalismen i folkbildningen mattades av efter kulmen under andra världskriget, men det fanns fortfarande en tro på en "god" nationskänsla som ett försvar mot

\footnotetext{
42 TSF 1966:9, 169.

43 TSF 1969:7, $390 f$.

44 Bygdeband.se, "Folkhögskolans rektorer" (http://www.bygdeband.se/wp-content/uploads/uploaded/417/200703_asa_20_21.pdf (hämtad 2017-01-04).

45 TSF 1954:2.

46 TSF 1954:2; TSF 1958:3.
} 
den farliga nationalismen. ${ }^{47}$ Tidens nationalism, nordism och skandinavism kan dock sägas ha ideologiska rötter som sträckte sig tillbaka till folkhögskolans begynnelse. Förstärkningen av patriotismen har, tillsammans med medborgarfostran, beskrivits som folkhögskolans två huvudsyften under 1800 -talets senare hälft. ${ }^{48}$ Även om den svenska folkhögskolan tidigt tog en egen inriktning, finns det också ett arv från Danmark, folkhögskoleföregrundgestalten Nikolaj Frederik Severin Grundtvig och det danska folkets nationella fostran via folkbildningen. ${ }^{49}$ Även idén om relationen mellan en delad nordisk identitet och folkbildning härrörde bland annat ur Grundtvigs skrivelser..$^{50}$

Det som sker i TSF under 50-talet är att den tidigare nationalismen måste omformuleras och ges ny innebörd. Både nationalismen och nordismen anses som "för trånga" för folkhögskolans ambitioner. Nedan antyds en diskursiv kamp mellan huruvida nordismen är förlegad eller ska ses som en nödvändig förlängning, mot en internationalism.

"nordiskt samarbete, nordism - det är för litet och trångt. Det är för begränsat. Den ti-
den är redan försutten. Nu är det Europa och världen, universum det gäller! ” förkun-
nar man som en märkvärdig nyhet eller upptäckt. Men det är ju därför vi gripit oss an
med det första och enklaste och nödvändigaste: nordiskt samarbete! [...] Charity be-
gins at home. - På 1920-talet formade professor Edvard Lehman slagordet "Europa er
mit Fädreland, men Danmark er mit Hjem!" Det är redan nu längesedan alla verkligt
arbetande nordister som ett motto och ledmotiv i sitt nordiska arbete omformat detta
ord på nutidens språk såhär: "Jorden är vårt fosterland, men Norden är vårt hem!"51

Nordismen framgår här som en slags utvidgning av nationen, eller "hemmet". Liksom i citatet ovan antyds en strävan efter ett världsmedborgarskap, där hela jorden ska bli ett fosterland. Det finns således inte ett ifrågasättande av nationalism eller patriotism i sig i talet om internationalisering, utan nationalism och patriotism framstår som naturaliserade och förgivettagna till sin karaktär: de ska bara utvidgas.

Den nationella samhörigheten framstår ofta tydligt som något som befolkningen måste fostras till. Men det finns också ett essentialistiskt antagande, där nationalismen och patriotismen förklaras som medfödd, och där internationalism måste förmedlas till befolkningen, exempelvis av utbildningsinstitutioner som folkhögskolan. Av citatet nedan att döma relaterar talet om en medfödd patriotism till en internationell utbildningsdiskurs inom FN:

FN:s undervisningsorgan Unesco påminner i sin målsättning om att en verklig internationalism och mellanfolklig förståelse måste inläras, medan vi alla föds till patriotism och nationalism. Vi måste skapa ett intresse för omvärlden för att utveckla en känsla av internationellt medansvar. ${ }^{52}$

47 Samuel Edquist, En folklig historia: historieskrivningen i studieförbund och hembygdsrörelse (Umeå: Boréa, 2009), 207.

48 Maliszewski (2008).

49 Ibid.

50 Leppänen (2011).

51 TSF 1960:3, 168f (emfas i original).

52 TSF 1969:6, $273 \mathrm{f}$ (emfas i original). 
Nationalismen omfamnas även på andra sätt i argumentationen för varför en internationalisering eller internationalism skulle införas i folkhögskolan, och då speciellt i det som kan räknas till u-landsfrågornas domän. I likhet med vad tidigare postkoloniala studier inom svensk forskning om folkbildning och bistånd påvisar, ${ }^{53}$ reproducerar även TSF en svensk nationell självbild som, modernt och demokratiskt i kontrast till "den andre" som porträtteras som bakåtsträvande. ${ }^{54}$ Denna bild är genomgående i materialet. Det finns ett retoriskt grepp som utgår från en tilltänkt olikhet som på olika sätt ska dämpas. Det sker genom skapandet av sameness, det vill säga att skildra redan andrefierade "andre" som lik den tilltänkte läsaren, i syfte att väcka empati och intresse för dennes levnadsvillkor. Det utgår alltså från att något sådant inte går att göra om "den andre" uppfattas som för olik en själv. Samtidigt som likhet (och en förutsatt skillnad) skapas på olika sätt, måste också en viss olikhet skildras för att skapa spänning, genom att spela på exotifierande fantasier om det imaginära u-landet. Likhetsdiskurserna fungerar också som ett sätt att ursäkta eller förklara företeelser som befaras vara för främmande för att läsaren ska ta till sig dem eller känna att de angår hen.

Det är mycket lätt att falla för en frestelse att beskärma sig över en okunnighet och vidskepelse av det här slaget. Men behåller man bara synen och inställningen att man bläddrar tillbaka i historiens stora bok, när man hamnar i ett land på efterkälken, är det inte svårt att se sammanhang och finna förklaringar. ${ }^{55}$

Som citatet ovan visar är ett sätt att skapa både igenkänning och exotifiering att använda sig av en föreställning som liknar allegorin U-land och Det förflutna. ${ }^{56}$ Detta är kanske mest framträdande under de tidigare åren då utlandsresor över huvud taget blev möjligt för lärare och rektorer vid de svenska folkhögskolorna. Resenärerna återkom ofta med ingående skildringar från resan, och som publicerades i TSF. I följande två artiklar från samma författare går jämförelsen mellan 1960-talets Etiopien och 1500-1800-talets Sverige som en röd tråd genom berättelserna:

Var och en som undervisar i historia har väl någon gång önskat sig tillbaka till någon
särskilt intressant period i det förgångna. [...] Att komma till ett s.k. underutvecklat
land och där leva i direkt kontakt med folket innebär i mångt och mycket, att man får
sin önskan om en färd tillbaka i historien uppfylld. ${ }^{57}$

Mellan tuggorna försökte jag på nytt att orientera mig i den svenska historien. Var hade jag hamnat? Det finns en mycket känd bild av Gustav III, där han sitter och äter med en del hovmän och adelsmän som åskådare. Men han sitter vid ett fint dukat bord, och man kan vara alldeles säker på att det var en bestämd ordning både på rätter

53 Jmf Dahlstedt och Nordvall (2011); Maria Eriksson Baaz, The Paternalism of Partnership: A Postcolonial Reading of Identity in Development Aid (New York/London: Zed Books, 2005); Ali Osman, The "Strangers" Among Us: The Social Construction of Identity in Adult Education (Linköping: Linköping University, 1999).

54 Jmf Johannes Fabian, Time and the Other: How Anthropology Makes Its Object (New York: Columbia University Press, 2014).

55 TSF 1960:2, 103f.

56 Jmf Fabian (2014).

57 TSF 1960:2, 103f. 
och cermoniel. Men en gästgivaregård under postdiligensernas tid eller en bondstuga kring år 1800 med herrgårdsfolket på överraskande besök? Det passade bättre, bestämde jag mig för, även om baron och friherrinnan väl knappast åt med fingrarna. Men så har vi ju också legat närmare franska seder och bruk än vad folket i Turkiet har gjort. ${ }^{58}$

Att relatera upplevelser till förgångna tider i Sverige blir således ett sätt att vädja till igenkänning hos den tilltänkte läsaren, samtidigt som den exotiserar och spännandegör erfarenheten. Allegorin framhäver också en nationell självbild, där svenskhet framstår som modern, demokratisk och civiliserad i motsats till den bakåtsträvande andre som äter med fingrarna och inte anses ha en bestämd ordning på vare sig rätter eller ceremoni. I skildringen framhävs också överhöghet, där skribenten automatiskt tillskriver sig en roll som överklass (och till och med kung!) i det sammanhang han hamnat i.

Det går att tolka allegorin U-land och Det förflutna som ett uttryck för det som tidigare forskning benämner som nationalromantiska strömningar i folkhögskolan. Den nationalromantiska laddningen i folkbegreppet och folkbildningen går att spåra tillbaka till 1800-talet och dess olika bildningsinitiativ i Sverige, som ofta initierades av den intellektuella övre medelklassen, som syftade till att ingjuta en känsla av gemenskap och nationalitet bland de lägre samhällsklasserna, något som tidigare inte var självklart. Samma typ av nationsskapande tendenser syntes även i Danmark under samma period, inte minst genom Grundtvig. ${ }^{59}$ Att anspela på nationalromantiska folkhögskolediskurser blir därmed ett led i skapandet av både likhet och spänning, och verkar fungera som ett sätt att väcka engagemang i utvecklingsfrågor.

\section{Säkerhetspolitisk folkbildning mot hotet från massorna}

[...] historiens tidsvattendrag som kommer att vända: de hungrande invånarna i de fattiga "trängselns och förtvivlans länder" kommer att hemsöka den vita minoriteten i en global klasskamp riktad mot den privilegierade överklassen i de rika industristaterna. $^{60}$

Citatet kommer från sent 60-tal och ger uttryck för eftervågen av ytterligare en dimension av nationalism: den säkerhetspolitiska. Den säkerhetspolitiska diskursen är en av dem som framkommer i argumentationen om varför folkhögskolan ska engagera sig i internationella frågor, och då särskilt "u-landsfrågorna". Farhågor lyfts om att allt för stora materiella globala klyftor kommer leda till ytterligare ett världskrig där u-länderna tillslut kommer göra revolution mot i-länderna. Det finns, framför allt under tidigt 60-tal, ett tydligt uttryckt nationellt säkerhetspolitiskt egenintresse av att på olika sätt minska denna klyfta. I TSF exemplifieras detta ytterligare med att militära termer såsom "upprustning för det internationella samarbetet" ${ }^{61}$ figurerar. Men också som i citatet nedan, med ekonomiska och politiska termer:

\footnotetext{
58 TSF 1962:1, s. $28 \mathrm{f}$

59 Henrik Nordvall, "Att bilda ett folk," i Nyttan med folklig bildning, red. Bernt Gustavsson och Matilda Wiklund (Lund: Nordic Academic Press, 2013), 34-61.

60 TSF 1968:2, $58 f$.

61 TSF 1954:2, 170.
} 


\begin{abstract}
Vi vet vad det kommer att innebära, om den klyfta som nu finns mellan länder på vår utvecklingsnivå och länder med etiopisk standard vidgas i stället för att minska. För vår egen skull - för att rädda vårt eget skinn, säger politiker och ekonomer med insikt i saken - måste vi göra stora ansträngningar för att i första hand dela med oss av våra kunskaper och erfarenheter. ${ }^{62}$
\end{abstract}

Hänvisningen till "politiker och ekonomer med insikt i saken" visar på hur texten tar avtryck ifrån en större samhällsdiskussion om internationellt bistånd och utrikespolitik som florerade under samma tid. Den allmänna uppslutningen kring biståndsfrågor som skedde var naturligtvis avhängiga maktpolitiska skeenden i efterkrigstidens, avkolonialiseringens och kalla krigets tidsera. Detta präglade såväl biståndsdebatten som debatten inom folkhögskolan. Etableringen av Sida gav upphov till stora debatter mellan näringsliv, folkrörelser, politiska partier och organisationer om syftet med myndigheten och biståndet. Motiven sträckte sig mellan att handla om ekonomi och säkerhetspolitik till att fokusera humanitära skäl och solidaritet. Idén om bistånd höll under tiden på att institutionaliseras i flera länder, och olika argument hade olika tyngd beroende på land. Frankrike fokuserade exempelvis sitt bistånd till de tidigare kolonierna, medan det i USA fanns en betoning på säkerhetspolitiska frågor som skäl till att ge utländskt bistånd. Trots att det fanns en stark förankring av folkrörelser inom Sidas föregångare Centralkommittén hade säkerhetspolitiska diskurser del av argumenten för etableringen av biståndet i Sverige. ${ }^{63}$

Ett säkerhetspolitiskt förhållningssätt var med andra ord del av biståndsdebatten, och i det folkhögskolesammanhang som TSF utgjorde reproducerades säkerhetspolitiken genom att omsättas i de diskurser som dikterade folkhögskolans funktion och uppdrag. En av folkhögskolans uppgifter blir därmed att på olika sätt folkbilda människor i syfte att stävja en potentiell revolution. Även här går konceptet att ideologiskt spåra tillbaka i den nordiska folkbildningens idéhistoria. Folkeopplysningen i Norge har beskrivits dels som ett filantropiskt projekt med rötter i upplysningsfilosofin och med syfte att fostra de lägre klasserna, dels som ett modernt projekt som skulle leda till utveckling och göra människan till "härskare över naturen". Liksom i Sverige fanns det strömningar som syftade till att trygga borgerskapets positioner och att förebygga massfenomen och social orolighet bland de breda folklagren. ${ }^{64}$ Det kan nämnas att även liknande diskurser florerade rörande biståndet under samma tidsepok. Nilsson menar att det fanns en tydlig linje i biståndsdebatten som bestod i att, bland annat via familjeplanering, hjälpa andra länder att komma tillrätta med överbefolkning och samtidigt stävja en befarad för stor invandring till Sverige. ${ }^{65}$ Rädslan för de stora, okontrollerbara massorna kan därför, i brytningspunkten mellan biståndets och folkhögskolans diskursordningar, sägas gå från att röra den inhemska arbetarklassen till att gälla den globala underklassen och utvecklingsländernas folk.

\footnotetext{
62 TSF 1960:2, 103f.
}

63 Per Åke Nilsson, Svenskt bistånd till den tredje världen: dess uppkomst under 1950-talet: En studie av SIDA:s och NIB:s föregångare - Centralkommittén för svenskt tekniskt bistånd till mindre utvecklade områden (Hammerdal: Hammerdal förl. och reportage, 2004).

64 Sigvart Tøsse, Folkbildning som universellt fenomen: Om betydelser och motsvarigheter $i$ historiskt och internationellt perspektiv (Linköping: Linköpings universitet, 2009).

65 Nilsson (2004). 
Rädslan för massorna hade inte bara materialistiska och välfärdsvurmande argument, utan kunde också ha rasistiska och koloniala undertoner, och där värnandet av ett föreställt svenskt folk eller ras som ska bevaras tar sig uttryck. Det pågår in på 60-talet diskussioner som speglas i TSF huruvida det skulle skapas möjligheter att låta stipendiater från utvecklingsländer studera på svenska folkhögskolor. Fördelarna med detta sågs dels vara att stipendiaterna kunde få hjälp och vägledning av folkhögskolorna, och dels att svenska elever "behöver konfronteras med ungdomar av annan ras och från annan kulturmiljö". ${ }^{66}$ Det fanns dock invändningar mot detta, där skribenten menar att folkhögskolan inte har tagit ställning i frågan om det "i det långa loppet är motiverat att satsa på färgade elever vid våra folkhögskolor”, samt refererar till en större offentlig diskussion som berör "lämpligheten av att över huvud taget placera asiater och afrikaner i vårt land" ${ }^{67}$ Det är således en debatt som framställs som helt legitim i tidskriftssammanhanget, och där det fortfarande är osäkert hur folkhögskolan som institution ska ställa sig till frågan.

Även om exempel som det ovan är få i materialet så är debatten i sig inte främmande. Det skrevs i relation till ett explicit rasbiologiskt paradigm, där den nationella självbilden var genomsyrat av idén om Sverige som ett rasialt homogent land och en del i en global vit elit som på olika sätt skulle skyddas från degenerering. Hübinette och Lundström kallar den här epoken för "white purity". ${ }^{68}$ Här kan sägas att denna form av hegemonisk vithet som genomsyrade samhället tog sig uttryck i, och reproducerades av, folkhögskolan och TSF, särskilt tidigare i historien. Folkbildningen blev under 1900-talets första del ett viktigt instrument för att motverka degenerering hos "den svenska folkstammen". Det fanns också interpersonella kopplingar mellan ledande folkbildningsideologer och rasbiologin som idé och institut. ${ }^{69}$ Exempel på det i det här sammanhanget är att TSF upplät annonsplats för en bok om rasbiologi skriven av den svenska, världsledande rasbiologen Herman Lundborg, ${ }^{70}$ samtidigt som både rasbiologi och rashygien studerades inom folkbildningen i Sverige i början av 1900-talet. ${ }^{71}$

Efter perioden av "white purity" följer, det som Hübinette och Lundström kallar "white solidarity", ${ }^{72}$ en anpassning till den nya världsordningen som präglades av avkolonialisering, och där den nationella självbilden i och med 68-perioden antog en antirasistisk och färgblind hållning. Det rasistiska och koloniala förflutna skuffades undan och strukturella problem tillskrevs andra länder än det egna. I TSF ändras diskurserna radikalt ju närmare 70-talet materialet kommer. Diskurserna får en mer humanitär karaktär och den rashygieniska retoriken är borta. Internationell samhörighet över nationsgränserna ses som en nödvändighet för att hantera de globala problemen och miljöfrågor blir allt mer aktuella. Dock riktas blicken mot väst och Sverige, och det som tidigare setts som tillväxt och förtjänad välfärd omformuleras i

66 TSF $1963: 1,7$.

67 Ibid.

68 Hübinette och Lundström (2014).

69 Nordvall (2013).

70 TSF 1922:4.

71 Edqvist (2009); Håkan Blomqvist, Nation, ras och civilisation i svensk arbetarrörelse före nazismen (Stockholm: Carlssons, 2006).

72 Hübinette och Lundström (2014). 
termer av privilegier och imperialism. Vid sidan av neutralitet och oskuld växer en postkolonial kritik fram, i likhet med de tendenser som syntes i svensk tv och olika folkbildande program under samma tidsepok. ${ }^{73}$

Rädslan för hotet från den globala underklassens massor lyser fortfarande igenom i slutet av 60-talet, men istället för att slå vakt om sitt eget hus betonas hela världens överlevnad eller undergång. Mer explicita protester hörs mot att "u-landshjälpen", och det aspirerande begreppet "solidaritetsarbetet", i första hand skulle handla om i-ländernas säkerhet. I ett internationellt temanummer från 1969 vänder sig redaktionen uttryckligen emot det tidigare tankesättet, samtidigt som de fortfarande understryker en risk för revolution:

Om inte de välutvecklade länderna gör något, kommer u-folket att i raseri rasera ra-
serisk rangordning. Vi är överens. Motivet är oftast fel. För att vi ska bestå, måste vi
hjälpa. Borde vara: För att de ska bestå måste vi hjälpa. Vilka är de? Människor! ${ }^{74}$

Filantropin, det goda samvetets accepterade huvudkudde, måste förvisas till illusionernas vaxkabinett. Dess ersättning: solidaritet. Solidaritet är medvetandet om att alla inte är programmerade på samma sätt, omsatt i praktisk konsekvens, saklig konsekvens utan bitanke på fårsida eller skydd för vad vi byggt upp. ${ }^{75}$

Citaten uttrycker en motdiskurs mot de tidigare av egenintresse förklarade argumenten, och ger därmed uttryck för att de säkerhetspolitiska förhållningssätten tidigare haft en relativt hegemonisk ställning, som redaktionen nu tydligt behöver ta avstånd ifrån. Här syns också hur solidaritetsbegreppet börjar ta plats i TSF, här som en ersättning av "filantropi". Övergången från att i första hand tala om hjälp till att tala om solidaritet är karaktäristiskt för tidpunkten, och går inte att isolera till enbart folkhögskolediskurser. Som tidigare beskrivits kan det ses som en del av globala samhällstendenser i och med 68-rörelsen, efterkrigstiden och avkolonialiseringen. Det reser också frågor om vem som blir folkbildningens subjekt, vilket leder oss in på nästa avsnitt.

\section{Folkbildning: Från hjälp till opinionsbildning}

Vi vet vilka krafter som frigjordes i vårt land och de andra nordiska länderna i och med att folkundervisningen blev allmän och folkhögskolan kom till bygden. Dessförinnan var vårt land ett fattighus, och murar av okunnighet och vidskepelse hindrade framsteg och reformer. Vi vet idag hur det kom sig, att vi lyckades ta oss ur detta tillstånd och har därför möjlighet att visa andra vägen och ge dem redskap i händerna för egna ansträngningar i samma riktning. [...] Vi har ingen patentmedicin för problem av det här slaget, men vi kan ge råd och anvisningar och vi kan hjälpa till att skapa arbetsformer och organ för en utveckling mot ett demokratiskt samhälle i västerländsk mening. ${ }^{76}$

73 Ylva Habel, "Filmen Vita myror som postkolonial kritik." I TV-pionjärer och fria filmare: En bok om Lennart Ehrenborg, red. Tobias Jansson och Malin Wahlberg, Mediehistoriskt Arkiv 9 (Stockholm: Statens Ljud- och Bildarkiv, 2008), 261-77.

74 TSF 1969:6, 273f (emfas i original).

75 Ibid.

76 TSF 1960:2, 103f. 
I citatet ovan går det att skönja såväl de säkerhetspolitiska som de nationalromantiska dragen. Men här fungerar säkerhetspolitik och nationalromantik också som ett sätt att placera folkhögskolan och dess uppgift i det imaginära u-landet; folkbildningen, det som lyfte Sverige ur fattigdom på 1800-talet, ska även fungera som hävstång för de samtida u-ländernas utveckling. I citatet ovan paketeras detta i medicinska termer såsom "tillstånd" och "patentmedicin". Bristen på "framsteg och reformer" patologiseras och boten går att finna i de svenska folkbildarnas "råd" och "anvisningar". "Den vite mannens börda" och idén om västs ansvar att upplysa och modernisera den ociviliserade andre, framträder som en av folkbildningens uppgifter i "u-land". Detta är också något som uppmärksammats rörande biståndsväsendet. ${ }^{77}$

Det leder oss in på idéer om folkhögskolans plats i det framväxande fältet för svenskt internationellt bistånd under 50- och 60-talen. Biståndet har beskrivits få en central roll i de internationella relationerna under efterkrigstiden, där bilden av Sverige som "misslyckades kolonisatörer" beredde vägen för att landet kunde positionera sig som en god aktör på den världspolitiska kartan. ${ }^{78}$ Sverige och Norge byggde sitt bistånd på en idé om att sakna ett kolonialt förflutet, samtidigt som de stora kolonialmakterna var framträdande biståndsgivare till de forna kolonierna. ${ }^{79}$ Detta kunde också användas som en fördel i den nygamla hjälparbetesgeografin som växte fram under samma period, ${ }^{80}$ och som folkhögskolan bevisligen också förhöll sig till. Framställandet av Sverige som en modern nation i framkant var också viktiga för 50-talet mobilisering av befolkningen i syfte att skapa välvilja till skattefinansierat bistånd och tillsättandet av en särskild myndighet för detta. Detta skedde bland annat via den statliga kampanjen "Sverige hjälper" ${ }^{81}$ Som ett svar på mobiliseringen pågick det på folkhögskolorna en egen version av "Sverige hjälper" under namnet "Folkhögskolan hjälper", och som proklameras i TSF. Kampanjen är ett tydligt exempel på en interdiskursivitet mellan de båda institutionernas diskursordningar och samspel i mobiliseringen för upprättandet av ett fält för svenskt internationellt bistånd.

Precis som tidigare påpekats finns det i materialet en tydlig modernistisk och eurocentrisk stadiesyn på utveckling, där "u-länderna" ses som "på efterkälken", och per definition förväntas följa samma utvecklingsväg som "i-länderna". Detta är mest framträdande på 50-talet och i början av 60-talet. Folkhögskolans roll blir här att vara rådgivande i utvecklingen mot demokrati " $i$ västerländsk mening". ${ }^{82}$ Generellt framstår folkhögskolerepresentanter som läromästare till det globala syd, som anses behövas utbildas i modernitet och demokrati. Flera av de konkreta projekt som beskrivs under 50- och 60-talen syftar till alfabetisering och praktisk utbildning såsom snickeri och sömnad, där de svenska folkbildarna inte helt sällan följer missionärernas spår och får i uppdrag att undervisa lokalbefolkningen i nämnda färdigheter, nedan i Tanzania.

\footnotetext{
77 Jmf Eriksson Baaz (2002).

78 Pernille Ipsen och Gunlög Fur, "Introduction," Itinerario 33, nr 2 (2009), 7-16.

79 Engh (2009), 65.

80 Jonsson (2012).

81 Se Maj-Britt Öhman, "'Sverige hjälper': Att fostra svenska folket till medvetenhet om sin egen storhet och andras litenhet," Tidskrift för Genusvetenskap 29, nr 1 (2008); Nilsson (2004).

82 TSF 1960:2, 103f.
} 


\begin{abstract}
Man behöver kunskaper om hur man ska göra vardagslivet mera uthärdigt, hur man ska sköta sin jord och sin boskap, hur man ska få bättre hälsa, och hur man ska sköta sina barn. I den modernare världens tekniska, ekonomiska och sociala ämnesområden behöver individen lära sig, hur han ska bli effektivare och med tekniska hjälpmedel förbättra sin situation. Man behöver lära sig hur man ska samarbeta med andra och hjälpas åt att utveckla sitt land - här kommer kooperationen in - och man behöver lära sig, hur landet fungerar. ${ }^{83}$
\end{abstract}

Det tidiga 60-talets debatt rörande huruvida Sverige överhuvudtaget skulle "ta hit Afrikaner och Asiater till vårt land" har svängt vid 60-talets slut. Stipendiaterna argumenteras nu istället kunna bidra till kunskapsökning hos svenska folkhögskoledeltagare och berika det svenska samhället. ${ }^{84}$ Stipendiaternas uppgift att upplysa den svenska publiken blir ett led i den opinionsbildning och informationsverksamhet som inträder som den nya doktrin som kom att prägla u-landslinjerna fram tills dags dagar, och där "hjälp" blir "opinionsbildning" och det globala syd förväntas bistå med (u-lands-) kunskap till det globala nord.

Biståndsdebatten svänger över lag starkt under det sena 60-talet och 70-talet. Idétraditioner såsom beroendeskolan, nymarxismen och biståndskritiken får fäste. Sverige börjar ge humanitärt bistånd till befrielserörelser, ${ }^{85}$ vilket även hade inverkan på utbildningsområdet. ${ }^{86}$ Olika befrielserörelser från olika delar av världen får ett större inflytande i Sverige, liksom kritiker från den biståndskritiska beroendeskolan, postkolonial teori och progressiv och frigörande pedagogik. Avkolonialiseringens Tanzania med den socialistiska presidenten Julius Nyerere görs i TSF till hopp om att socialistiska samhällen och "revolution genom utbildning"87 är möjligt. Det politiska intresset för Tanzania etablerar sig på svenska folkhögskolor under 60-talets slut och är starkt än idag.

Även inom TSF började intern kritik av maktrelationer i folkbildande verksamheter lyftas. Kvinnliga författare samt i viss utsträckning författare med rötter i det globala syd börjar tala tillbaka mot den manliga, vita och västerländska formuleringen av u-landsproblematiken och folkbildningen i TSF.

Vi vet att den information vi får om andra människor, antingen genom massmedia
eller i våra skolböcker, är långt ifrån objektiv och nyanserad. Att det finns en allmänt
utbredd okunnighet om främmande länder kan inte minst den som kommer från ett
av dessa länder intyga. Den upplysning som ska ge, bör syfta till dels att ge objektiva
kunskaper om främmande människor, dels skapa positiva attityder till ömsesidigt be-
roende. Den bör således inte gå ut på att visa att vi har det bra och andra har det dåligt,
och därmed skapa en känsla av medlidande gentemot andra människor. Detta är nå-
gonting om är långtifrån det jag kallar ömsesidigt. Det tycks nämligen skapa det rakt
motsatta, en överlägsenhetskänsla, en känsla av att man är den som hjälper och inte
den som behöver hjälp. [...] Istället för att enbart samla pengar till u-landshjälp, vilket
man givetvis bör göra, skulle man kunna satsa just på att upplysa individen och hos

83 TSF 1969:6, 298.

84 TSF 1969:7, 385f.

85 Odén (2006).

86 Maliszewski (2008).

87 TSF 1969:4. 
henne skapa denna känsla av ansvar för medmänniskan, inte på grund av medlidande utan med insikt om det ömsesidiga beroendet. ${ }^{88}$

"U-landshjälpen" bör nu istället bedrivas i form av samarbete, och samarbete ska byggas på ömsesidighet med utgångspunkten att alla parter har något att lära. Ömsesidigheten kan ses som en motdiskurs till den gemene u-landsbilden som skapats via kampanjer såsom "Sverige hjälper". Men skribenten i citatet ovan belyser också den som i TSF framträder som den nya rollen för folkhögskolan: upplysning av den egna svenska befolkningen i form av information och opinionsarbete. Från att ha varit inriktat på konkret, praktisk hjälp i det imaginära u-landet blir "u-landsinformationen" ett av de primära uppdragen att informera befolkningen i Sverige, inte minst dem i den egna rörelsen. De u-landslinjer som växer fram under det sena sextio- och tidiga 70-talet får en starkare opinionsbildande roll.

Sammantaget innebär det en skiftning från att u-landsarbetet under 50- och 60-talen främst handlar om att den svenska folkhögskolan och dess folkbildare har mycket att lära ut och hjälpa till med, till att under 70-talet i större utsträckning handla om vad Sverige och svenska folkbildningen kan lära av det globala syd. Det sker en förskjutning från ett mer klassiskt filantropiskt förhållningssätt, där svenska folkbildare åker till ett utvecklingsland som biståndsarbetare för att bidra med kunskap och materiella resurser, till att under sent 60-tal och 70-tal i större utsträckning prata om solidaritet, där opinionsbildning och "medvetandegörande" på hemmaplan står i fokus.

\section{Slutdiskussion}

Jag har i den här artikeln sökt spårat några av de diskurser om internationalisering, utveckling och bistånd som föregick det som kom att bli särskilda u-landslinjer på folkhögskolan, samt diskursiva förändringar över tid. Fokus har legat på att spåra förändring, ideologi och relationer av makt i Tidskrift för svenska folkhögskolan samt att relatera det till omgivande samhällsordning för tidsepoken. Jag har ställt frågor till materialet angående varför och hur folkhögskolan skulle bli internationell, vilka som skulle beröras och vilken innebörd internationalisering ges i folkhögskolekontexten. Vidare har jag försökt utröna idéer om folkhögskolans roll i ett framväxande fält för svenskt internationellt bistånd. Empirin visar hur talet om internationalisering går hand i hand med begreppet u-land. U-landsbegreppet i sin tur går från att knappt existera till att bli etablerade institutioner och koncept för folkhögskolans engagemang i svenskt internationellt bistånds- och solidaritetsarbete. I slutänden materialiseras debatten om folkhögskolans roll i utvecklingsfrågor i de särskilda u-landslinjerna, som i mångt och mycket har bevarat sin ursprungliga form, med resemoment och opinionsbildning, till dags dagar.

Resultaten visar också att talet om internationalism i mångt och mycket tar avstamp i en i folkbildningen redan etablerad nationalism och nordism, samt att säkerhetspolitiska motiv framträdde i argumenten för varför folkhögskolan skulle engagera sig i utvecklingsfrågor. Folkhögskolans uppgift i det framväxande utvecklingsarbetet skiftar från att "hjälpa" till att "opinionsbilda". Alla tre resultaten relaterar på olika sätt till nation, nationell kultur och skapandet av rasiala maktrelationer,

88 TSF 1969:7, 385 (emfas i original). 
formade av den koloniala världshistorien. ${ }^{89}$ De visar också på förändringar över tid $i$ takt med den internationalisering som sker som ett resultat av globaliseringen. ${ }^{90}$

Folkhögskolan framträder i TSF som redan från början se sin roll som medborgarfostrande, nationsbyggande och folkbildande aktör, både i opinionen för, och arbetet med, svenskt internationellt bistånd. Utifrån olika ideologiska strömningar tar sig idén om bildning, fostran och vad som ska förmedlas, och hur, olika uttryck över tid. Detta gäller inte minst u-landsfrågorna. Vem som ska folkbildas blir under 60-talet föremål för förändring. Om texterna tidigare formulerat ett tydligt "vi" som med modernisering och demokratisering via folkbildning ska hjälpa ett "dem", börjar ljuset riktas mot det egna landet och dess medborgare. Nu är det svenskarna som anses behöva upplysning om "u-landproblematiken", något som kan tolkas som en ökad internationalisering $i$ en accelererande globalisering, och därmed skulle också befolkningen på olika sätt rustas inför det. ${ }^{91}$ Syd förväntas här bistå med "u-landskunskap" till det allt mer kosmopolitiserande Nord.

Med hjälp av begreppet interdiskursivitet visar jag på hur diskurser från biståndets diskursordning träder in på folkhögskolans. Folkhögskolans självbild och uppgift går från en djup och uttalad nationell och nordisk förankring och avgränsning, till att gå mot en självförståelse som internationell och gränsöverskridande med engagemang för internationell solidaritet och det framväxande biståndet. Materialet ger exempel på när talet om internationalism tar avstamp i olika former av nationalism och nordism, även med rötter i nationalistiska och/eller rasistiska ideologier som hade satt sin prägel i folkhögskolan och det svenska samhället i stort. Detta syns inte minst i den säkerhetspolitiska argumentation som gjorde avtryck under delar av tidsepoken. Här sammanflätas folkbildningens tidigare funktion som revolutionsstävjare $^{92}$ med biståndets säkerhetspolitiska lidelser för att säkra det egna landets välfärd: ${ }^{93}$ Folkbildning och bistånd framstår här som en lyckosam kombination för kontroll av de farliga massorna, och fokus flyttas från att röra den svenska underklassen till att röra den globala.

Stadieteori och tron på industriell (och kulturell) "utveckling" som något nödvändigt, deterministiskt och linjärt, är vidare tydlig under 50- och stora delar av 60-talet. I ett Sverige som framställs som modernt och i framkant, spelar både ett, vad jag kallar, exotifierande av samtiden och nationalromantiserande av det förgångna en roll i argumentationer för att folkhögskolan skulle engagera sig i utvecklingsfrågor. För att tala med Hall utgör de "memories which connect its present with its past"94 $\mathrm{i}$ åberopandet av nationella folkhögskoleidentiteter. Samtidigt som de relaterar till en antropologisk tradition av hur "anthropology makes its others" ${ }^{\text {"95 }}$ genom tid. Retoriken kan läsas som ett sätt att försöka överbrygga skillnad mellan den tilltänkte läsaren och det imaginära u-landet, samt att göra u-ländernas folk både intresse-

\footnotetext{
89 Jmf Loftsdottir och Jensen, red. (2012); Keskinen et al. (2009); Anderson (1983); Hall (1996). 90 Jmf Altbach och Knight (2007), 290.

91 Ibid.

92 Jmf Jenny Jansson, Manufacturing Consensus: The Making of the Swedish Reformist Working Class (Uppsala: Uppsala University, 2012); Nordvall (2013).

93 Nilsson (2004).

94 Hall (1996), 613.

95 Fabian (1983).
} 
väckande och sörjbara för en tilltänkt folkhögskolepublik. Bilden utmanas i slutet av 60-talet av en framväxande revolutionär och anti-imperialistisk anda, då 68-rörelsen gjorde avtryck i folkhögskolan. Talet om det homogeniserade u-landet går under den här perioden till att dels bli mer lokal och specifik, dels till att erkänna politisk agens, då de lokala, regionala och världspolitiska villkor börjar beskrivas ingående och flera olika röster börjar få mer utrymme i tidskriften.

Ovanstående blir intressant mot bakgrund att både biståndet och folkbildningen har fyllt och fyller viktiga funktioner för upprättandet och upprätthållandet av svensk nationell identitet. Liksom bistånd och arbete för mänskliga rättigheter, snarare än kolonialism och imperialism, är en central del i Sverigebilden ${ }^{96}$ har folkbildning, liksom ett demokratiskt sinnelag, historiskt sett lyfts fram som något säreget kulturellt svenskt. ${ }^{97}$ Folkhögskolan kan här sägas röra sig genom en tid av "white purity" till att på olika sätt ta sig an uppgiften att bidra till upprättandet av "white solidarity" och den framväxande kosmopolitiska andan. ${ }^{98}$ Samtidigt ingår folkhögskolan i en postkolonial kritisk genre, som växer sig starkare under 70-talet, och där systemkritik mot imperialism, kapitalism och kolonialism utgör kärnan i argumentationerna.

De tydliga kopplingar till nationalism, säkerhetspolitik och diskurser om hjälp och opinionsbildning i TSF väcker frågor om hur vi kan förstå dagens folkhögskolekurser i global utveckling i ljuset av 50- och 60-talens diskurser. På vilket sätt förhåller sig folkhögkolans kurser i global utveckling till biståndet och folkbildningens historiska arv och samtida premisser? Och vilka möjligheter för solidaritetsarbete bereds kurserna idag utifrån rådande världspolitiska och historiska förutsättningar? Mer forskning skulle behövas kring samtida villkor för folkhögkolans kurser i global utveckling samt för de samarbetsorganisationer som är kopplade till dem.

96 Keskinen et al. (2009).

97 Nordvall (2013); Dahlstedt och Nordvall (2011); jmf Osman (1999).

98 Hübinette och Lundström (2014). 


\section{Referenser \\ Otryckta källor}

Bygdeband.se. "Folkhögskolans rektorer"

(http://www.bygdeband.se/wp-content/uploads/uploaded/417/200703_asa_20_21. pdf (hämtad 2017-01-04).

\section{Tryckta källor och litteratur}

Altbach Philip G. och Jane Knight, "The Internationalization of Higher Education: Motivations and Realities," Journal of Studies in International Education 11, $\mathrm{nr}$ 3-4 (2007), 290-305.

Andersén, Annelie. Ett särskilt perspektiv på högre studier? Folkhögskoledeltagares sociala representationer om högskola och universitet. Jönköping : Högskolan i Jönköping, 2011.

Anderson, Benedict. Imagined Communities: Reflections on the Origin and Spread of Nationalism, London: Verso, 1983.

Berg, Linda. InterNacionalistas: Identifikation och främlingskap i svenska solidaritetsarbetares berättelser från Nicaragua. Umeå: h:ström, 2007.

Berndtsson, Rolf. Nya folkhögskolor: En uppföljningsstudie av de folkhögskolor som blivit självständiga mellan åren 1991 och 2000. Stockholm: Folkbildningsrådet, 2003.

Blomqvist, Håkan. Nation, ras och civilisation i svensk arbetarrörelse före nazismen. Stockholm: Carlssons, 2006.

Dahlstedt, Magnus och Henrik Nordvall. "Paradoxes of Solidarity: Democracy and Colonial Legacies in Swedish Popular Education." Adult Education Quarterly 61, nr 244 (2011).

Edquist, Samuel. En folklig historia: Historieskrivningen i studieförbund och hembygdsrörelse. Umeå: Boréa, 2009.

Engh, Sunniva. "The Conscience of the World? Swedish and Norwegian Provision of Development Aid." Itinerario 33, nr 2, (2009), 65-82.

Eriksson Baaz, Maria. The Paternalism of Partnership: A Postcolonial Reading of Identity in Development Aid. New York/London: Zed Books, 2005.

Fabian, Johannes. Time and the Other: How Anthropology Makes Its Object. New York: Columbia University Press, 2014.

Fairclough, Norman. Critical Discourse Analysis: The Critical Study of Language. 2nd Edition. Harlow: Longman, 2010.

Fairclough, Norman. Discourse and Social Change. Cambridge: Polity, 1992.

Habel, Ylva. "Filmen Vita myror som postkolonial kritik." I TV-pionjärer och fria filmare: En bok om Lennart Ehrenborg, red. Tobias Jansson och Malin Wahlberg, 261-77. Mediehistoriskt Arkiv 9. Stockholm: Statens Ljud- och Bildarkiv, 2008.

Hall, Stuart. "The Question of Cultural Identity." I Modernity: An Introduction to Modern Societies, red. Stuart Hall, David Held, Don Hubert och Kenneth Thompson. Malden: Blackwell, 1996.

Hettne, Björn. Vad är utveckling? Stockholm: SNS förlag, 2008.

Hyldgaard Nankler, Clara. "Folkhögskolans globala engagemang." Årsbok om folkbildning. Stockholm: Föreningen för folkbildningsforskning, 2014.

Hübinette, Tobias och Catrine Lundström. "Three Phases of Hegemonic Whiteness: Understanding Racial Temporalities in Sweden." Social Identities: Journal for the study of Race, Nation and Culture 20, nr 6 (2014), 423-37. 
Ipsen, Pernille och Gunlög Fur. ”Introduction.” Itinerario 33 (2009), 7-18.

Jansson, Jenny. Manufacturing Consensus: The Making of the Swedish Reformist Working Class. Uppsala: Uppsala University, 2012.

Jonsson, Cecilia. Volontärerna: Internationellt hjälparbete från missionsorganisationer till volontärresebyråer. Växjö : Linnéuniversitetet, 2012.

Keskinen, Suvi, Salla Touri, Sara Irni och Diana Mulinari. Complying with Colonialism: Gender, Race and Ethnicity in the Nordic Region. New York: Routledge, 2009.

Landström, Inger. "Den nordiska folkhögskolans globala medborgare: Folkbildningspedagogik med internationella förtecken.” I Två sidor av samma mynt? Folkbildning och yrkesutbildning vid de nordiska folkhögskolorna, red. Fay Lundh Nilsson och Anders Nilsson. Lund: Nordic Academic Press, 2010.

Lazar, Michelle, red. Feminist Critical Discourse Analysis: Gender, Power, and Ideology in Discourse. New York: Palgrave Macmillan, 2005.

Leppänen, Katarina. "Education for Internationalism at the Nordic School for Adult Education in Geneva 1931-1939." History of Education 40, nr 5 (2011), 635-49.

Loftsdóttir, Kristín och Jensen, Lars, red. Whiteness and Postcolonialism in the Nordic Region: Exceptionalism, Migrant Others and National Identities. Farnham: Ashgate, 2012.

Maliszewski, Tomasz. Den svenska folkhögskolan: En betraktelse från andra sidan Östersjön. Linköping: Vuxenutbildarcentrum, 2008.

Nilsson, Per Åke. Svenskt bistånd till den tredje världen: Dess uppkomst under 1950-talet: En studie av SIDA:s och NIB:s föregångare - Centralkommittén för svenskt tekniskt bistånd till mindre utvecklade områden. Hammerdal: Hammerdal förl. och reportage, 2004.

Nordvall, Henrik. "Att bilda ett folk." I Nyttan med folklig bildning, red. Bernt Gustavsson och Matilda Wiklund, 34-61. Lund; Nordic Academic Press, 2013.

Nordvall, Henrik och Magnus Dahlstedt. "Folkbildning i (av)koloniseringens skugga." Utbildning \& Demokrati 18, nr 3 (2009), 29-47.

Nylander, Erik och Song-Eeh Ahn. "Vart leder internationaliseringen?" I Lärandets mångfald: Om vuxenpedagogik och folkbildning, red. Andreas Fejes 209-29. Lund: Studentlitteratur, 2013.

Nylander, Erik, Kerstin Mustel och Therése Jansson. Gränsöverskridande folkbildning: Om resurser, nätverk och transnationellt engagemang. Stockholm: Folkbildningsrådet, 2011.

Odén, Bertil. Biståndets idéhistoria: Från Marshallhjälp till millenniemål. Lund: Studentlitteratur, 2006.

Osman, Ali. The "Strangers" Among Us: The Social Construction of Identity in Adult Education. Linköping: Linköping University, 1999.

Runesdotter, Caroline. I otakt med tiden? Folkhögskolorna i ett föränderligt fält. Göteborg: Göteborgs universitet, 2010.

Tidskrift för svenska folkhögskolan (TSF), 1950-1969.

Triandafyllidou, Anna och Ruth Wodak. "Conceptual and Methodological Questions in the Study of Collective Identities." Journal of Language \& Politics 2, nr 2, (2003), 205-23.

Tøsse, Sigvart. Folkbildning som universellt fenomen: Om betydelser och motsvarigheter $i$ historiskt och internationellt perspektiv. Linköping: Linköpings universitet, 2009. 
Wallin, Kerstin E. Folkbildning på export? Sammanhang, förutsättningar, möjligheter. Stockholm: Stockholms universitet, 2000.

Weiss, Gilbert och Ruth Wodak, red. Critical Discourse Analysis: Theory and Interdisciplinarity. Basingstoke: Palgrave Macmillan, 2002.

Wodak, Ruth, red. The Discursive Construction of National Identity. 2 ed. Edinburgh: Edinburgh University Press, 2009.

Wodak, Ruth och Salomi Boukala. "European identities and the revival of nationalism in the European Union: a discourse-historical approach." Journal of Language \& Politics 14, nr 1 (2015), 87-109.

Wodak, Ruth och Michael Meyer, red. Methods of Critical Discourse Analysis. London: SAGE, 2001.

Öhman, Maj-Britt. '"Sverige hjälper': Att fostra svenska folket till medvetenhet om sin egen storhet och andras litenhet." Tidskrift för Genusvetenskap 29, $\mathrm{nr}$ 1, (2008), 58-77.

Österborg Wiklund, Sofia. "Från u-landslinje till global rättvisekurs: Om resande kurser i folkhögskolans kurskataloger 1983-2014." I Folkbildning \& forskning: årsbok 2014/15. Stockholm: Föreningen för Folkbildningsforskning, 2015. 